\title{
居住小区容积率空间差异 以大连市为例
}

\author{
李雪铭 ${ }^{1,2}$, 朱健亮 ${ }^{*^{*}}$, 王 勇 1,3 \\ (1. 辽宁师范大学城市与环境学院, 辽宁 大连 $116029 ; 2$. 辽宁师范大学人居环境研究中心, 辽宁 大连 116029 ; \\ 3. 大连市国土资源发展研究中心, 辽宁大连 116009)
}

\begin{abstract}
摘要: 以土地利用中居住小区及房屋调查数据为基础、居住小区为基本研究单元, 通过 GIS 技术和泰尔指数模型, 对大连市居住小区容积率空间差异进行实证研究。先应用 GIS 技术对居住小区容积率进行计算, 其次将居住小区 容积率划分为 7 个等级并对居住小区进行容积率分级, 应用 GIS 软件生成空间分布图和等值线图, 然后应用泰尔 指数计算居住小区容积率空间差异测度指数, 最后分析其形成原因。结果表明: 1)大连市居住小区容积率呈不同 等级整体破碎、相同等级小范围集聚、邻近等级穿插结合的空间分布特征。(2)连市居住小区容积率整体分异测 度指数不高, 极低和极高容积率等级的居住小区差异测度最大; 全市四大区域中, 中山区差异测度最大, 甘井子区 差异测度最小, 四大区域的内部差异测度远远大于各区域之间的差异测度, 是大连市居住小区容积率空间差异的 显著特点。(3)居住小区容积率空间差异的主要原因是城市不同区位和房屋属性所形成的住宅类型指向、城市空间 地貌对居住小区建设的制约、城市居住用地规划标准的宏观导向、城市地价对容积率的作用。
\end{abstract}

关键词: 容积率; 空间差异; 居住小区; 泰尔指数; 大连

\section{1 引言}

城市居住空间分异是近年来国内城市地理学 研究的热点问题之一, 起源于西方国家对种族隔离 问题的研究。西方学者认为不同种族之间存在着 文化及信仰等社会空间差异, 从而导致城市居住空 间分异(Simpson, 2004)。在国外,20世纪 20 年代美 国芝加哥学派已经开始对城市居住空间分异进行 研究(Park et al, 1925), 目前已经形成了比较成熟的 理论与方法。国内对城市居住空间分异的研究起 步较晚, 1986年虞蔚发表的《城市社会空间的研究 与规划》(虞蔚, 1986), 是国内城市居住空间分异研 究较早的文献。城市居住空间分异不但具有空间 属性上的居住类型、环境、设施等分异, 同时还具有 社会属性上的居住群体、经济、生活方式等分异(宋
伟轩等, 2010), 学者们通过不同视角对城市居住空 间分异作了系统研究,主要包括居住类型空间分异 (廖邦固等, 2012)、居住空间结构分异(廖邦固等, 2008; 袁雯等, 2010)、社会空间分异(李志刚等, 2006; 冯健等, 2008; Itzhak, 2010)、文化空间分异(薛 东前等, 2011)、住宅价格空间分异(Koramaz et al, 2012; 王洋等, 2013, 2014)、经济空间分异(Omer et al, 2012; 余凤鸣等, 2012)等。在研究方法上, 国内 外常用的有因子生态分析法、调查问卷法、聚类分 析法、分异测度指数法等定量与定性分析方法, 尤 其近些年 GIS 技术的广泛应用为城市居住空间分 异研究提供了有效的技术方法支持。

容积率最早在 1957 年被美国土地规划管理部 门作为一项重要的控制性指标, 被称为 Floor Area Ratio(FAR), 在英国被称为 Plot Ratio, 两者的含义

收稿日期: 2014-11; 修订日期: 2015-03。

基金项目:国家自然科学基金项目(41171137); 教育部博士点基金项目(20132136110001); 辽宁省高等学校优秀人才支持计划 项目(LR2013050)。

作者简介: 李雪铭(1964-), 男, 江苏常熟人, 教授, 博士生导师, 主要从事城市人居环境与城市社会地理研究,

E-mail: lixueming999@163.com。

通讯作者:朱健亮(1987-), 男,辽宁铁岭人,硕士研究生,主要研究方向为城市人居环境,E-mail: zhuj1529@163.com。

引用格式: 李雪铭, 朱健亮, 王勇. 2015. 居住小区容积率空间差异: 以大连市为例[J]. 地理科学进展, 34(6): 687-695. [Li X M, Zhu J L, Wang Y. 2015. Spatial differences of residential quarter floor area ratio: a case study of Dalian[J]. Progress in Geography, 34(6): 687-695.]. DOI: $10.18306 /$ dlkxjz.2015.06.004 
相同。容积率自 20 世纪 80 年代传人中国, 是《控制 性详细规划》中的重要指标, 在城市地价与城市规 划等方面发挥了重要作用。容积率综合城市建筑、 人口、土地利用、社会经济和城市环境等各个方面 的利益, 具有经济性、社会性和环境性(鲍振洪等, 2010)。目前, 国内外对容积率的研究主要集中在 容积率的估算、容积率调控、容积率与房价、容积率 与交通、容积率与土地利用强度等方面。例如, Irvin 等(1989)在 20 世纪 80 年代利用航空影像研究了 建筑物及其阴影之间的关系, 为以后容积率的估算 提供了方法, 而后许多学者利用遥感影像对容积率 进行估算; Joshi 等(2009)从容积率调控和优化的角 度探讨城市土地集约利用; Ong(2003)提出了城市 绿化建设的一个新规划指标——绿色容积率, 与城 市建筑容积率十分相似, 并应用到了实际的规划工 作中。近些年, 国内对容积率的研究也取得了丰硕 的成果, 如查勇(2001)对测定城市建筑容积率的遥 感方法进行了研究; 陈昌勇 $(2006,2012)$ 对城市容积 率的确定方法和机制进行了研究; 王冰寒(2008)以 西安市为例, 研究了容积率对地价的影响规律及其 如何确定修正系数; 谭艳慧(2010)以济南市为例, 研 究了住区容积率与居住形态的演变及相互关系; 渠 涛等(2010)以轨道交通的视角研究了容积率的规划 方法; 赵守谅(2004)对容积率进行了经济分析等。

近年来, 由于房价的快速上涨, 开发商为追逐 高额利润, 在房地产业广泛采用高容积、低密度的 开发模式, 导致居住小区容积率越来越高。然而, 过高的容积率会使居住小区产生日照不足、人口密 度增大、环境质量恶化、交通流量过高和基础设施 承载力不足等一系列问题, 直接影响居住区的人居 环境质量。随着生活水平的不断提高, 人们所追求 的高质量居住环境不仅仅是居住空间的大小, 还要 考虑安全、舒适、整洁、方便等因素, 建设宜居城市 同样要考虑到城市居民的居住、生活、工作和居住 者的心理感受(李雪铭等, 2008), 而容积率是衡量一 个居住小区人居环境质量的重要指标。以往对居 住空间分异研究多采用遥感影像解译划分居住类 型以及调查小区房价而进行; 在居住小区容积率的 研究中较多以居住小区容积率设计、改善措施、指 标体系等为基础。如杨新和(2004)从住宅单体和居 住小区设计层面上对小区容积率进行了住宅类型 因素分析和小区布局设计研究; 袁重芳等(2008)通 过对重庆市五大主城区的居住小区楼盘调查, 总结
了居住小区容积率现状并提出改善措施; 张亚洲 (2008)通过居住区的布局、环境和用地条件等相关 的指标因素对居住小区容积率进行了研究等;而应 用具体数据进行计算分析居住小区容积率的空间 差异尚未见到。大连市作为东北区域最大港口和 海滨旅游城市, 发展水平较高, 由于其特殊的滨海 区位和丘陵地貌,是研究城市居住空间分异的重要 案例城市。基于此, 对大连市居住小区容积率进行 空间差异研究, 可为城市居住空间结构优化、城市 人居环境的协调和可持续发展提供理论和实践 支持。

本文根据所获得的大连市居住小区数据, 从居 住小区容积率的视角研究城市居住空间分异。通 过对大连市居住小区容积率进行等级划分, 分析了 大连市居住小区各等级容积率在空间上的分布现 状, 应用泰尔指数模型, 对大连市居住小区容积率 整体分异测度、各等级分异测度、四大区域之间和 内部分异测度进行了定量研究, 分析了居住小区容 积率空间分异的主要原因, 以此为城市规划和建设 部门提供参考。

\section{2 数据与方法}

\section{1 研究区域与基础数据}

大连市位于辽东半岛南端, 地处黄渤海之滨, 与山东半岛隔海相望。通常大连主城区的范围包 括市内 4 个区, 即: 中山区、沙河口区、西岗区和甘井 子区, 其中甘井子区面积远远大于其他 3 个区, 但城 市发展水平明显不如其他 3 个区, 且甘井子区西部 和西北部居住小区较少, 为了便于研究, 本文将大 连市中心城区作为研究区域,包括中山区、沙河口 区、西岗区的全部和甘井子区邻近其他 3 个区的大 部分地块区, 研究区域的地理位置和范围如图 1。

数据来源于 2010 年大连市第二次土地调查中 的主城区 1:500 城镇地籍调查数据, 以大连市居住 小区面积、居住小区楼盘数量、楼盘基底面积和层 数为基础数据资料; 以居住小区边界矢量图、主要 交通、区划等空间要素底图为基础图像资料,将大 连市交通、城市规划、Google 图像等数据作为辅 助。对于部分居住小区内部住宅类型及楼盘信息 以实地调查为准, 同时参考了大连搜房网 (http://dl. fang.com/)、新浪乐居(http://dl.esf.sina.com.cn/)等网 站的有关信息。 


\section{2 居住小区容积率计算}

本文的研究对象以居住小区为基本单元。在 大部分的居住小区内, 居住类型相同或相似; 部分 居住小区是混合户型, 会出现不同的居住类型。例 如一个居住小区有可能出现低层和多层的混合住 宅类型, 本文将计算每个居住小区的平均容积率, 即居住小区容积率=居住小区总建筑面积/居住小 区用地面积, 且只计算居住小区地上容积率, 即居 住小区地上总建筑面积, 不计地下车库和仓库的面 积。通过小区内部所有的楼房基底面积和层数可 以计算出每个小区内部的地上建筑总面积, 再除以 小区总占地面积即为对应小区的容积率。计算过 程为: 首先通过 ArcGIS 软件对居住小区边界范围 图层和居住小区住宅楼图层进行叠加, 再提取两个 图层中的居住小区面积属性和小区内每一栋楼基 底建筑面积、楼层属性, 对大连市居住小区容积率 进行计算, 得出研究区域各个小区的容积率具体数 值。居住小区分布和小区内楼房分布如图2。

\section{3 居住小区容积率等级划分}

有些居住小区内部住宅类型会有明显差异, 如 有 $\mathrm{A}$ 区、 $\mathrm{B}$ 区和 $\mathrm{C}$ 区, $\mathrm{A}$ 座、 $\mathrm{B}$ 座和 C座, I 期、II 期和 III期, 东区、北区和南区的居住小区, 为满足研究需 要, 进行一定的整合和拆分, 最终共形成 956 个研究 单元。由于每个居住小区的容积率都不是几个固 定的特殊数值, 即使是同类型的居住小区, 容积率

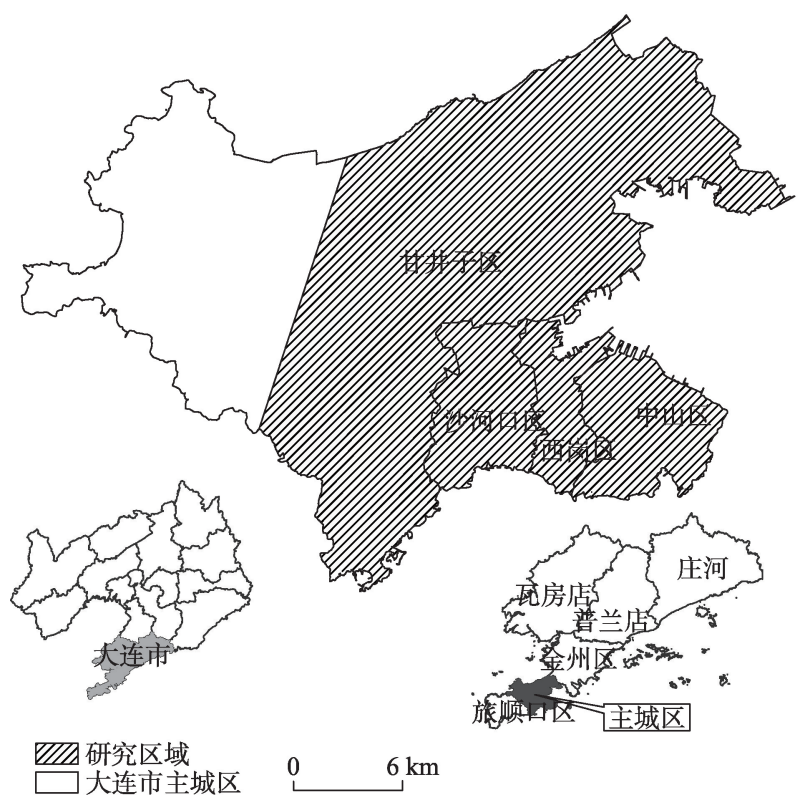

图 1 研究区域位置和范围

Fig.1 Location and spatial extent of the study area
也有一定的差值, 根据《大连市控制性详细规划指 标》并结合大连市居住小区实际情况, 将大连市居 住小区容积率划分为极低、低、中低、中、中高、高和 极高 7 个等级,每个居住小区的容积率等级对应可 能的住宅类型, 根据已掌握的数据资料计算大连市 居住小区容积率, 依据已划分的居住小区容积率等 级,得到各等级容积率居住小区个数(表 1 )。

\section{4 空间差异测度指数}

目前, 国内外对于空间差异定量研究的数学统 计方法较多,主要有Duncan等(1955)提出的分异指 数法,许多学者应用此方法进行空间分异的定量研 究(李志刚等, 2006; 马慧强等, 2011; 廖邦固等, 2012); 传统的差异指数方法包括变异系数、泰尔指

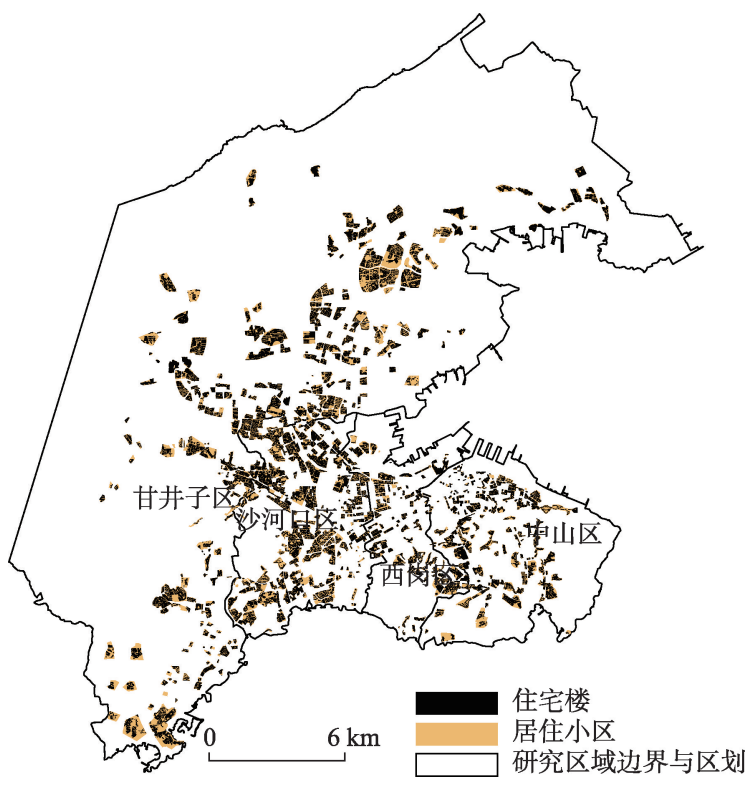

图 2 大连市居住小区和住宅楼分布

Fig.2 Distribution of residential quarters and residential buildings in Dalian

表 1 大连市居住小区容积率等级划分

Tab.1 Classification of residential quarter floor area ratio in Dalian

\begin{tabular}{lrlr}
\hline $\begin{array}{c}\text { 容积率 } \\
\text { 等级 }\end{array}$ & \multicolumn{1}{c}{ 容积率范围 } & \multicolumn{1}{c}{ 可对应的住宅类型 } & $\begin{array}{r}\text { 居住小 } \\
\text { 区个数 }\end{array}$ \\
\hline 极低 & 容积率 $\leqslant 0.3$ & 高档独栋别墅 & 17 \\
低 & $0.3<$ 容积率 $\leqslant 0.8$ & 一般独栋、双拼、联排别墅 & 43 \\
中低 & $0.8<$ 容积率 $\leqslant 1.2$ & 花园洋房、低层 & 198 \\
中 & $1.2<$ 容积率 $\leqslant 1.5$ & 多层 & 225 \\
中高 & $1.5<$ 容积率 $\leqslant 2.0$ & 多层、小高层混合 & 220 \\
高 & $2.0<$ 容积率 $\leqslant 3.0$ & 小高层 & 108 \\
极高 & $3.0<$ 容积率 $\leqslant 6.0$ & 高层 & 145 \\
\hline & & &
\end{tabular}


数、基尼系数、总熵指数和阿特金森指数等,在空间 差异研究中均有广泛的应用(刘慧, 2006)。因为空 间分异更多地与社会现象有关, 容积率属于客观差 异, 所以采用传统的差异指数方法对大连市居住小 区容积率空间差异进行计算。由于泰尔指数法在 计算空间差异时不仅可计算研究对象的总体差异 程度, 还可将总体的区域差异分解成不同组别的内 部差异和组别之间的外部差异, 将研究对象的空间 差异剖析的更加全面, 目前在不同研究对象的区域 空间差异研究中应用广泛(徐建华等, 2005; 修春亮 等, 2008; 李敏纳等, 2009; 康晓娟等, 2010; 王洋等, 2013), 所以本文用泰尔指数来计算大连市居住小 区容积率的空间差异, 公式如下:

$$
T=\frac{1}{n} \sum_{i=1}^{n} \frac{x_{i}}{\bar{x}} \log \frac{x_{i}}{\bar{x}}
$$

式中: $T$ 为泰尔指数, $n$ 为居住小区个数, $x_{i}$ 为第 $i$ 个小区的容积率, $\bar{x}$ 为居住小区容积率均值。泰尔 指数的数值范围在 $0 \sim 1$ 之间, 数值越大表明分异程 度越大, 0 为无分异, 1 为完全分异。

根据泰尔指数的特殊性, 可将整体分异测度分 解为不同组别之间的分异测度和不同组别的内部 分异测度, 因表 1 将容积率从低到高划分为 7 个等 级, 如果按照各个容积率等级进行分组, 计算结果 必然会导致等级之间的差异度会很高, 所以划分组 别时采用空间位置进行分组, 将研究区域按照区划 分为 4 个组, 分别为中山区、西岗区、沙河口区和甘 井子区。各组所包含的居住小区个数见表 2 。

由(1)式可将泰尔指数进行分解:

$T=T_{b}+T_{w}=\sum_{k=1}^{K} \frac{x_{k}}{y_{k}} \log \frac{x_{k} / y_{k}}{n_{k} / n}+\sum_{k=1}^{K} \frac{x_{k}}{y_{k}}\left(\sum_{i \in g_{k}} \frac{x_{i}}{x_{k}} \log \frac{x_{i} / x_{k}}{1 / n_{k}}\right)$ (2)

式中: $T_{b}$ 与 $T_{w}$ 分别为不同组别之间的分异测度和不 同组别内部分异测度; $K$ 为居住小区总体所划分的 不同组别数量 (本文 $K=4$ ), 每组中小区个数分别为 $g_{k}(k=1,2, \cdots, K) ; n_{k}$ 为第 $k$ 组别中居住小区数量； $x_{k}$ 为第 $k$ 组别中居住小区的容积率之和; $y_{k}$ 为所有 居住小区容积率之和。其他指标解释与(1)式相 同。各等级容积率的差异测度与各组别容积率差 异测度计算公式与总体差异测度计算公式相同, 只 是将样本数目控制在某一容积率等级或某组别中 的个体数目。

\section{3 结果与分析}

\section{1 空间分布特征}

根据计算出的居住小区容积率和所划分的居 住小区容积率等级, 对研究区域内的各个居住小区 进行容积率分级。通过 ArcGIS 对大连市居住小区 边界图、主要交通道路和行政区划底图进行叠加, 生成大连市居住小区容积率空间分布图(图 3)。

通过大连市居住小区容积率空间分布图(图 3) 可以看出: 大连市居住小区容积率空间分布呈不同 等级整体破碎、相同等级小范围集聚、邻近等级穿 插结合的特征。极低和低等级容积率居住小区主 要分布在星海湾至老虎滩的滨海区、劳动公园、南 山宾馆附近地段的别墅区, 甘井子区近几年新开发 的地段也有部分极低和低等级容积率的居住小 区。中低和中等级容积率居住小区分布广泛, 各个 地段都有分布,但主要集中在沙河口区西部以及甘 井子区, 即在大连市西部分布较多, 在大学附近也 大多分布着中低和中等级容积率居住小区,小区的 居住类型以低层和多层为主。中高等级容积率居 住小区大部分布在大连市西部和北部区域, 以一般

表 2 研究区域 4 个组包含的居住小区个数

Tab.2 The number of residential quarters in the four districts of the study area

\begin{tabular}{ccccc}
\hline 组别 & 中山区 & 西岗区 & 沙河口区 & 甘井子区 \\
\hline 居住小区个数 & 243 & 129 & 265 & 319 \\
\hline
\end{tabular}

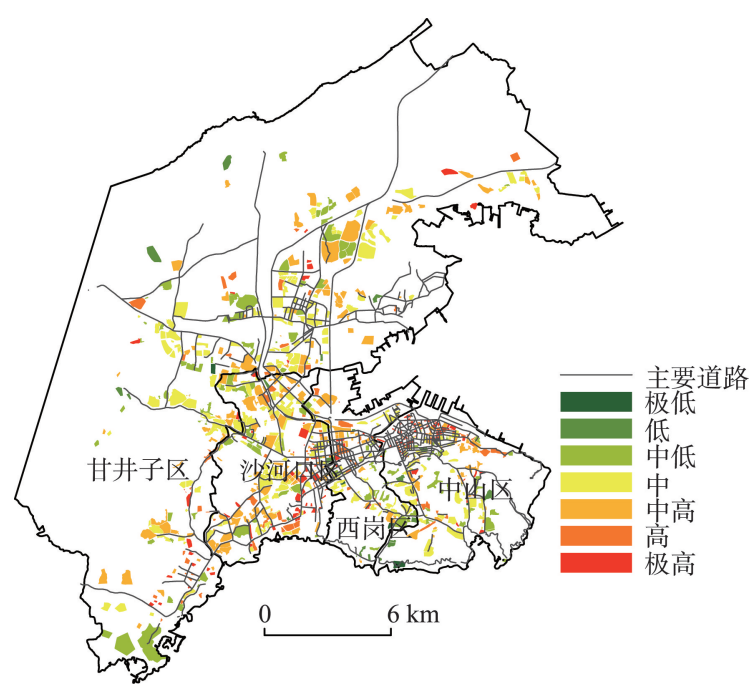

图 3 大连市居住小区各等级容积率空间分布

Fig.3 Spatial distribution of residential quarter floor area ratio classes in Dalian 
的多层和小高层类型为主。高和极高容积率居住 小区主要分布在大连市商业繁华且靠近交通线的 商业区和滨海高层海景房区域, 如中山广场附近的 商业区, 星海湾和甘井子区北部附近的海景房区, 居住类型以小高层和高层为主。从图上可以看出, 这些小区斑块绝大多数面积非常小, 而又由于其特 殊的区位, 楼房较高, 所以形成了相对的高容积率 小区。

利用 MapInfo、Surfer 等 GIS 软件, 以面状小区 的质心点为基础数据生成大连市居住小区容积率 等值线图(图4)。

通过大连市居住小区容积率等值线图(图 4)可 以看出: 等值线图上有 3 个主要核心区域,分别为: 中山广场区域、星海湾区域和甘井子区北部区域。 这 3 个主要核心区等值线密集, 跨度大, 分布着多个 高容积率等级的居住小区, 并有极高容积率等级的 居住小区, 究其原因是中山广场区域为商业核心 区, 土地开发强度大, 小区的占地面积较小, 楼层 高, 其外延又分布着普通住宅小区和别墅区; 星海 湾区域分布着高级别墅区、低层住宅小区和小高层 海景房; 甘井子区北部居住小区较少, 主要为海景 房和普通住宅或公寓式小区。这 3 个片区的特点是 居住小区容积率差异大, 由于居住小区容积率高低 分布导致了等值线图密集和颜色差异大。等值线 相对稀疏的区域主要分布在沙河口区北部和甘井 子区西部, 这些区域居住小区容积率差异小且容积 率等级适中, 居住小区分布相对分散, 所以等值线 稀疏, 颜色差异小。

\section{2 空间差异测度}

根据式(1)分别计算研究区域整体居住小区容

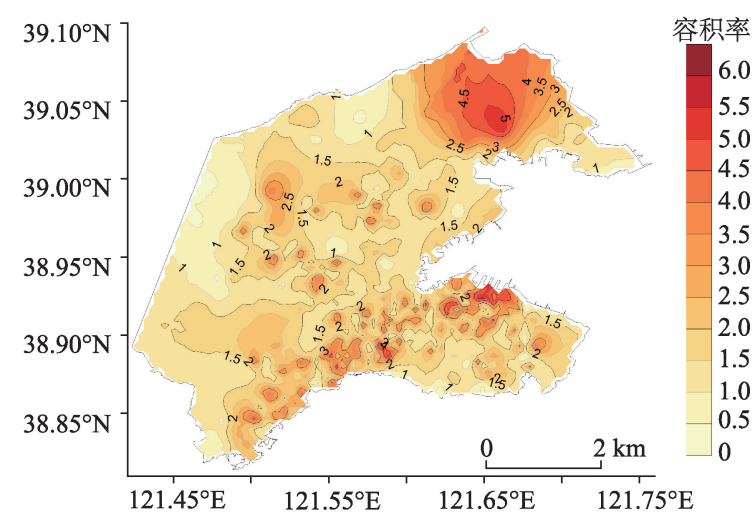

图 4 大连市居住小区容积率等值线图

Fig.4 Contour map of residential quarter floor area ratio in Dalian
积率空间差异测度指数与四大区域的空间差异测 度指数, 结果见表 3 。

由表 3 可以看出: 大连市居住小区容积率整体 差异测度指数并不是很高, 四大区域的居住小区容 积率空间差异测度指数与研究区域整体的居住小 区容积率差异测度指数较为接近, 其中最高的为中 山区,其差异测度指数超过了研究区域整体的空间 差异测度, 其次为沙河口区和西岗区, 最低的为甘 井子区, 这说明中山区内居住小区容积率等级跨度 大、分布均衡性最差, 其后为沙河口区和西岗区, 而 甘井子区居住小区容积率等级跨度最小、分布均衡 性最好。

再由公式(1)计算大连市居住小区各等级容积 率的空间差异指数,结果见表 4 。

由表 4 可以看出: 所划分的 7 个居住小区容积 率等级中, 极低等级容积率分异度在所有容积率等 级中最高,其次是极高等级,其余 5 个容积率等级的 居住小区空间分异度相差不大, 这说明极低和极高 两个容积率等级的居住小区相对于其他容积率等 级的居住小区差异较大, 也是不同等级容积率的居 住小区之间产生空间差异的两个主要等级。

根据公式(2)算计所划分的四大区域之间和内 部的空间差异测度指数, 由公(2)式中 $T=T_{b}+T_{w}$, 用 方程两边同时除以 $\mathrm{T}$ 得 $\frac{T_{b}}{T}+\frac{T_{w}}{T}=1$, 即 $\frac{T_{b}}{T}$ 和 $\frac{T_{w}}{T}$ 分 别为所划分的不同区域之间的分异测度与不同区 域的内部分异测度对整体分异测度的贡献率,结果 见表 5。

由表 5 可以看出: 所划分的四大区域内部差异 测度指数远远大于区域间的空间差异测度, 这说明 大连市居住小区容积率空间差异在 4 个大区内部差 异明显; 在区域之间差异很小,任意两个区之间未

\section{表 3 研究区域整体与四大区域居住小区容 积率空间差异测度指数}

Tab.3 Spatial difference index of residential quarter floor area ratio in the study area and its four districts

\begin{tabular}{cccccc}
\hline 区域 & \multicolumn{4}{c}{ 中山区 西岗区 沙河口区 甘井子区 研究区域整体 } \\
\hline 差异测度指数 & 0.268 & 0.208 & 0.229 & 0.187 & 0.244 \\
\hline
\end{tabular}

表 4 大连市居住小区各等级容积率空间差异测度指数

Tab.4 Spatial difference index of various residential quarter floor area ratio class in Dalian

容积率等级 极低 低 中低 中 中高 高 极高 
表 5 大连市居住小区容积率不同区域间与区域内 分异指数及其贡献率

Tab.5 Difference index and contribution rate of residential quarter floor area ratio within and between the districts in Dalian

\begin{tabular}{lccc}
\hline & 区域间 & 区域内 & 整体 \\
\hline 差异测度指数 & 0.072 & 0.172 & 0.244 \\
贡献率 & 0.295 & 0.705 & 1.000 \\
\hline
\end{tabular}

产生非常明显的差异。从贡献率上来看, 区域内的 贡献率为 0.705 , 是形成大连市居住小区容积率空 间差异的主导因素, 换言之, 四大区域内部居住小 区容积率的差异较大, 从而主导了整个大连市居住 小区容积率的空间差异; 四大区域之间的差异对总 体差异的影响很小。

\section{3 空间差异的主要原因}

根据居住小区容积率的影响因素, 结合大连城 市特殊特点, 总结出大连市居住小区容积率空间分 异的主要原因如下:

(1) 城市不同区位及房屋属性所形成的住宅类 型指向

滨海区位环境优美, 居住类型一般有高档别墅 和小高层海景房, 分布着极低、低和少数高等级容 积率的居住小区; 中心商务区周边和公交线路两旁 的居住小区受到用地规模的限制，楼层高、密度大， 分布着高和极高等级容积率的居住小区; 与海边和 商业区距离较远的一般住宅地带容积率适中, 分布 着中低、中和中高等级容积率的居住小区,住宅类 型一般为低层、多层和少数小高层; 学区附近的居 住小区一般为低层和多层住宅类型, 容积率也较为 适中; 20 世纪 90 年代所建设的居住小区住宅类型 一般多为低层和多层, 而目前居住小区建设多样 化, 尤其随着经济条件的改善, 别墅群和高层海景 房的增多对居住小区容积率的分布产生很大影响; 另外, 小区的产权属性和房产类型也不同程度影响 着居住小区建设的住宅类型,所以区位因素和小区 房屋属性是影响居住小区容积率空间差异的重要 原因。

(2) 城市空间地貌差别对居住小区建设的制约

大连市为丘陵地貌, 地势的高低与坡度影响着 居住小区的建设。地势较为平坦、坡度较小的地域 与地势较高、坡度较大的地域所建设的居住小区类 型不同, 地貌对居住小区的建筑密度和高度也有很 大影响, 从而影响居住小区的容积率。
(3) 城市居住用地规划标准的宏观导向

城市规划部门对土地开发强度有一定的标准, 容积率是土地开发强度的一项重要指标, 考虑到经 济因素、景观因素和环境因素,城市规划部门会对 居住小区的开发强度、建筑密度和高度分区等进行 一系列相关标准的调控,对部分特殊区域也会进行 特殊的规划政策,如某些区域限制楼房高度,为进 行交通疏导限制高层住宅区的过度集聚等,从而影 响了居住小区容积率的空间分布。

(4) 城市地价对容积率的作用

容积率具有经济性,城市中心、滨海、学校等区 域由于其区位优势使得土地集约度高, 地价也高; 新开发的城市郊区由于周边配套设施少,地价低, 开发商为了达到经济效益,地价的高低也就导致了 对地块的开发强度, 从而形成了相应的居住小区容 积率。

上述四种原因中,空间地貌差别影响不同区位 住宅类型、不同区位地价和城市居住用地规划标 准; 不同区位地价影响不同区位住宅类型; 居住用 地规划标准影响不同区位住宅类型和不同区位的 地价, 因此四种原因之间存在着相互关联影响。不 同区位和房屋属性与城市空间地貌差别共同驱动 住宅楼房高度; 居住用地规划标准和不同区位地价 共同驱动着建筑密度、高度和地块的开发强度,亦 即是四种原因中存在着相互影响和共同的驱动因 素, 由此形成了大连市居住小区容积率的空间分异 格局(图 5)。

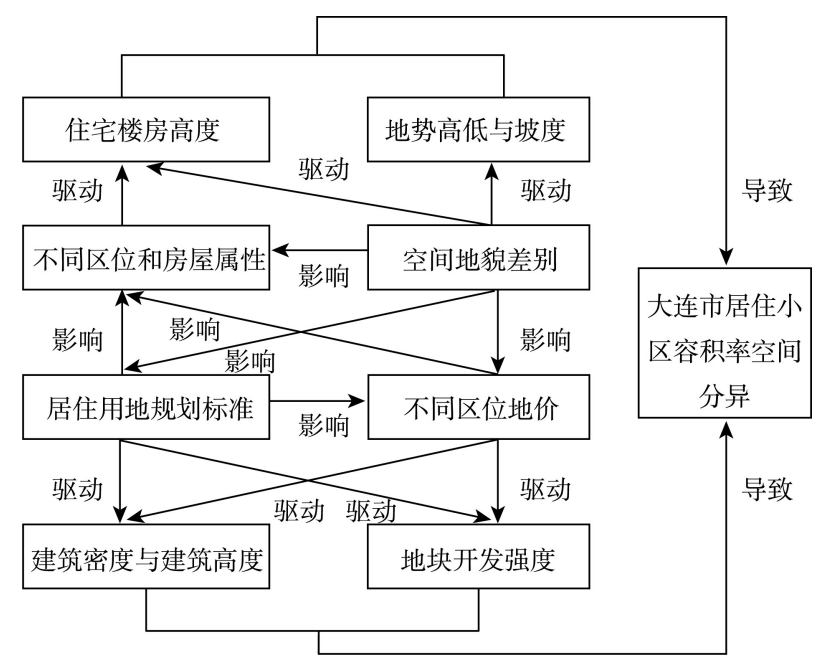

图 5 大连市居住小区容积率空间差异的主要原因

Fig.5 Main causes of spatial differentiation of residential quarter floor area ratio in Dalian 


\section{4 结论与讨论}

(1) 以土地利用中居住小区及房屋调查数据为 基础对大连市居住小区容积率进行计算, 得到的结 果客观真实地反映了大连市居住小区容积率空间 差异的现状。在空间分布上, 大连市居住小区没有 特大范围的相同容积率等级片区, 居住小区容积率 的各等级分布破碎, 以中低、中和中高容积率等级 的居住小区较多,相同容积率等级的居住小区形成 小范围集聚且相邻等级有一定的穿插结合, 极低和 极高两个容积率等级的居住小区在空间分布上显 得较为突出, 小范围之内的城市居住梯度较小。从 空间差异测度指数上看, 整个大连市的居住小区容 积率空间差异测度指数与 4 个大区的空间差异测度 指数相近, 中山区空间差异测度指数最大, 其内部 均衡性较差, 甘井子区差异测度指数最小, 均衡性 较好; 极低和极高容积率等级居住小区差异测度指 数明显大于其他容积率等级居住小区分异测度指 数, 说明这两个容积率等级的居住小区在空间分布 上差异明显;全市所划分的 4 个大区内部差异显著, 由 4 个大区的内部差异造成了整个大连市的空间差 异,而 4 个大区之间的差异对整体的差异影响很小; 大连市居住小区容积率空间差异与 4 个大区的空间 差异具有高度的关联性。全市居住小区容积率的 空间差异的主要原因是城市不同区位和房屋属性 所形成的住宅类型指向、城市空间地貌对居住小区 建设的制约、城市居住用地规划标准的宏观导向、 城市地价对容积率的作用。四种原因之间的相互 影响和共同驱动形成了大连市居住小区容积率的 空间分异格局。

(2) 本文以居住小区容积率的视角来探讨城市 居住空间分异,探索其现状和形成原因, 目的在于 更好地为居住小区建设及改善人居环境服务,所划 分的居住小区容积率等级以大连城市居住小区现 状为参考, 由于居住小区容积率形成的原因十分复 杂, 在分析原因时也是基于大连市特有的城市要素 为基础进行相关分析, 借此抛砖引玉, 是否能为不 同城市提供借鉴还有待实践检验。由于长时间序 列的居住小区数据资料较难以获取, 本文根据 2010 年的大连市第二次土地利用调查中的地籍调查数 据对居住小区容积率进行实证研究, 因城市居住小 区在时间上会有拆迁、改造和新建, 居住小区容积 率格局会在时间上有新的变化,城市内部居住小区
容积率的时间尺度变化会在以后作进一步的研究。

\section{参考文献(References)}

鲍振洪, 李朝奎. 2010. 城市建筑容积率研究进展 [J]. 地理科 学进展, 29(4): 396-402. [Bao Z H, Li C K. 2010. Progress on the study of urban architecture FAR[J]. Progress in Geography, 29(4): 396-402.]

陈昌勇. 2006. 城市住宅容积率的确定机制 [J]. 城市问题,

(7): 6-10. [Chen C Y. 2006. Assuring mechanism about floor area ratio of the dwelling house[J]. Urban Problems, (7): 6-10.]

陈昌勇. 2012. 城市住区容积率的确定方法 [J]. 城市问题, (2): 46-50. [Chen C Y. 2012. The method of determining the floor area ratio of city residential district[J]. Urban Problems, (2): 46-50.]

冯健, 周一星. 2008. 转型期北京社会空间分异重构 [J]. 地理 学报, 63(8): 829-844. [Feng J, Zhou Y X. 2008. Restructuring of socio- spatial differentiation in Beijing in the transition period[J]. Acta Geographica Sinica, 63(8): 829844.]

康晓娟, 杨东民. 2010. 基于泰尔指数法的中国能源区域差 异分析 [J]. 资源科学, 32(3): 485-490. [Kang X J, Yang D M. 2010. An analysis on the difference of regional energy consumption in China based on the method of the Theil index[J]. Resources Science, 32(3): 485-490.]

廖邦固, 徐建刚, 梅安新. 2012. 1947-2007年上海中心城区 居住空间分异变化: 基于居住用地类型视角 [J]. 地理研 究, 31(6): 1089-1102. [Liao B G, Xu J G, Mei A X. 2012. Evolution of residential differentiation in central Shanghai City (1947-2007): a view of residential land-use types [J]. Geographical Research, 31(6): 1089-1102.]

廖邦固, 徐建刚, 宣国富, 等. 2008. 1947-2000年上海中心城 区居住空间结构演变 [J]. 地理学报, 63(2): 195-206. [Liao B G, Xu J G, Xuan G F, et al. 2008. Evolution of residential space structure in Shanghai central city based on land use[J]. Acta Geographica Sinica, 63(2): 195-206.]

刘慧. 2006. 区域差异测度方法与评价 [J]. 地理研究, 25(4): 710- 718. [Liu H. 2006. Regional inequality measurement: methods and evaluations[J]. Geographical Research, 25(4): 710-718.]

李敏纳, 覃成林, 李润田. 2009. 中国社会性公共服务区域差 异分析[J]. 经济地理, 29(6): 887-893. [Li M N, Tan C L, Li R T. 2009. An analysis of regional social public services development difference in China[J]. Economic Geography, 29(6): 887-893.]

李雪铭, 刘秀洋, 冀保程. 2008. 大连城市社区宜居性分异特 征 [J]. 地理科学进展, 27(4): 75-81. [Li X M, Liu X Y, Ji B C. 2008. The principium research of community lodge- 
able polarization in Dalian[J]. Progress in Geography, 27 (4): 75-81.]

李志刚, 吴缚龙. 2006. 转型期上海社会空间分异研究 [J]. 地 理学报, 61(2): 199-211. [Li Z G, Wu F L. 2006. Socio spatial differentiation in transitional Shanghai[J]. Acta Geographica Sinica, 61(2): 199-211.]

马慧强, 韩增林, 江海旭. 2011. 我国基本公共服务空间差异 格局与质量特征分析 [J]. 经济地理, 31(2): 212-217. [Ma H Q, Han Z L, Jiang H X. 2011. The characteristics and spatial difference of basic public services of cities at prefecture level and above in China[J]. Economic Geography, 31(2): 212-217.]

渠涛, 蔡建明, 张理茜, 等. 2010. 轨道交通导向下的容积率 规划 [J]. 地理学报, 65(2): 202-212. [Qu T, Cai J M, Zhang L Q, et al. 2010. Research on floor area rate planning guide of railway traffic[J]. Acta Geographica Sinica, 65(2): 202-212.]

宋伟轩, 吴启焰, 朱喜钢. 2010. 新时期南京居住空间分异研 究 [J]. 地理学报, 65(6): 685-694. [Song W X, Wu Q Y, Zhu X G. 2010. Residential differentiation of Nanjing in the new period[J]. Acta Geographica Sinica, 65(6): 685694.]

谭艳慧. 2010. 住区容积率与居住形态的演变及相互关系研 究[D]. 济南: 山东建筑大学. [Tan Y H. 2010. Research on development and interrelationship of residential district's FAR and residential morphology[D]. Jinan, China: Shandong Jianzhu University.]

王冰寒. 2008. 容积率对地价的影响规律及其修正系数的确 定: 以西安市为例 [J]. 地理与地理信息科学, 24(2): 7780. [Wang B H. 2008. Affection regularity to land price and determination of the revising coefficient of floor area ratio in and appraisal: a case study of Xi'an[J]. Geography and Geo-Information Science, 24(2): 77-80.]

王洋, 方创琳, 盛长元. 2013. 扬州市住宅价格的空间分异与 模式演变 [J]. 地理学报, 68(8): 1082-1096. [Wang Y, Fang C L, Sheng C Y. 2013. Spatial differentiation and model evolution of housing prices in Yangzhou[J]. Acta Geographica Sinica, 68(8): 1082-1096.]

王洋, 李强, 王少剑, 等. 2014. 扬州市住宅价格空间分异的 影响因素与驱动机制 [J]. 地理科学进展, 33(3): 375388. [Wang Y, Li Q, Wang S J, et al. 2014. Determinants and dynamics of spatial differentiation of housing price in Yangzhou[J]. Progress in Geography, 33(3): 375-388.]

修春亮, 赵映慧, 宋伟. 2008. 1990年以来东北地区铁路运输 的空间极化 [J]. 地理学报, 63(10): 1097-1107. [Xiu C L, Zhao Y H, Song W. 2008. Spatial polarization of railway transport in northeast China: 1990-2005[J]. Acta Geographica Sinica, 63(10): 1097-1107.]
薛东前, 刘虹, 马蓓蓓. 2011. 西安市文化产业空间分布特征 [J]. 地理科学, 31(7): 775-780. [Xue D Q, Liu H, Ma B B. 2011. Characteristics of spatial distribution of cultural industries in urban area of Xi'an City, China[J]. Scientia Geographica Sinica, 31(7): 775-780.]

徐建华,鲁凤, 苏方林, 等. 2005. 中国区域经济差异的时空尺 度分析 [J]. 地理研究, 24(1): 57-68. [Xu J H, Lu F, Su F L. et al. 2005. Spatial and temporal scale analysis on the regional economic disparities in China[J]. Geographical Research, 24(1): 57-68.]

余凤鸣, 张阳生, 周杜辉, 等. 2012. 基于 ESDA-GIS 的省际边 缘区经济空间分异: 以呼包鄂榆经济区为例 [J]. 地理科 学进展, 31(8): 997-1004. [Yu F M, Zhang Y S, Zhou D $\mathrm{H}$, et al. 2012. Analyzing provincial border-regional economic disparities based on ESDA and GIS: a case study of Hohhot-Baotou-Ordos-Yulin Economic Zone[J]. Progress in Geography, 31(8): 997-1004.]

虞蔚. 1986. 城市社会空间的研究与规划 [J]. 城市规划, (6): 25-28. [Yu W. 1986. Research and planning of city social space[J]. City Planning Review, (6): 25-28.]

袁重芳, 李娟, 毛瑞勇. 2008. 重庆居住小区建筑容积率研究 分析及改善措施 [J]. 重庆建筑大学学报, 30(1): 26-29. [Yuan C F, Li J, Mao R Y. 2008. Research on improvement measures for building volume of residential quarters in Chongqing[J]. Journal of Chongqing Jianzhu University, 30(1): 26-29.]

袁雯, 朱喜钢, 马国强. 2010. 南京居住空间分异的特征与模 式研究: 基于南京主城拆迁改造的透视 $[\mathrm{J}]$. 人文地理, (2): 65-69. [Yuan W, Zhu X G, Ma G Q. 2010. A study on the features and models of residential space differentiation: a case study of Nanjing City[J]. Human Geography, (2): 65-69.]

杨新和. 2004. 城市住区设计中的建筑容积率研究 [D]. 西安: 西安建筑科技大学. [Yang X H. 2004. A study on floor area ratio in the design of urban residential district[D]. Xi'an, China: Xi'an University of Architecture and Technology.]

赵守谅. 2004. 容积率的定量经济分析方法研究[D]. 武汉: 华 中科技大学. [Zhao S L. 2004. The quantitative economic analysis method of floor area ratio[D]. Wuhan, China: Huazhong University of Science and Technology.]

查勇. 2001. 测定城市建筑容积率的遥感方法研究 [J]. 地理 科学进展, 20(4): 378-383. [Zha Y. 2001. A study on remote sensing methods in estimating urban built- up volume ratio based on aerial photographs[J]. Progress in Geography, 20(4): 378-383.]

张亚洲. 2008. 居住区容积率指标及其相关因素的研究 [D]. 天津: 天津大学. [Zhang Y Z. 2008. A study on index and 
its related factors of residential district floor area ratio

[D]. Tianjin, China: Tianjin University.]

Duncan O D, Duncan B. 1955. Residential distribution and occupational stratification[J]. American journal of sociology, 60(5): 493-503.

Irvin R B, Mckeown D M. 1989. Methods for exploiting the relationship between buildings and their shadows in aerial imagery[J]. IEEE Transactions on Systems, Man and Cybernetics, 19(6): 1564-1575.

Itzhak O. 2010. Residential differentiation at tow geographic scales- the metropolitan area and the city: the case of Tel Aviv[J]. Journal of Urban and Regional Analysis, 2(2): 63-79.

Joshi K K, Kono T. 2009. Optimization of floor area ratio regulation in a growing city $[\mathrm{J}]$. Regional Science and Urban
Economics, 39(4): 502-511.

Koramaz T K, Dokmeci V. 2012. Spatial determinants of housing price values in Istanbul[J]. European Planning Studies, 20(7): 1221-1237.

Omer I, Goldblatt R. 2012. Urban spatial configuration and socio- economic residential differentiation: the case of Tel Aviv[J]. Computers, Environment and Urban Systems, 36 (2): 177-185.

Ong B L. 2003. Green plot ratio: an ecological measure for architecture and urban planning $[\mathrm{J}]$. Landscape and urban planning, 63(4): 197-211.

Park R E, Burgess E W, McKenzie R D. 1925. The city Chicago[M]. Chicago, IL: Chicago University Press.

Simpson L. 2004. Statistics of racial segregation: measures, evidence and policy[J]. Urban Studies, 41(3): 661-681.

\title{
Spatial differences of residential quarter floor area ratio: a case study of Dalian
}

\author{
LI Xueming ${ }^{1,2}$, ZHU Jianliang ${ }^{1 *}$, WANG Yong ${ }^{1,3}$ \\ (1. School of Geography and Urban Environment, Liaoning Normal University, Dalian 116029, Liaoning, China; \\ 2. Institute of Human Settlement, Liaoning Normal University, Dalian 116029, Liaoning, China; \\ 3. Land and Resources Development Research Center of Dalian, Dalian 116009, Liaoning, China)
}

\begin{abstract}
Based on land use in the residential quarter and housing survey data and using residential quarter as the basic spatial unit, this study examines spatial differences of residential quarter floor area ratio using GIS technology and the Theil index model. It first calculates the residential quarter floor area ratio in GIS, then divides residential quarter floor area ratio into 7 classes and generates a spatial distribution map and a contour map in GIS. It then uses the Theil index to calculate the spatial differentiation index of residential quarter floor area ratio, and analyzes the causes. The results indicate that: (1) Spatial distribution of floor area ratio classes in the study area presents an overall fragmented pattern. Residential quarters with the same floor area ratio are clustered in small areas, and similar classes are interspersed. (2) Spatial difference index of residential quarter floor area ratio in Dalian is low. Maximal spatial difference index values are found in residential quarters with extremely low and high floor area ratios. The maximum and minimum spatial difference index values occurred in the Zhongshan and Ganjingzi Districts. Differences within each of the four districts are far greater than the regional differences between these districts and this is a remarkable characteristic of spatial difference index values of residential quarter floor area ratio in Dalian. (3) The main causes of the spatial differences of residential quarter floor area ratio in Dalian is the location of residential quarters in the city and housing attributes that determined the types of the housing; constraints imposed on residential quarter construction by the topography of the city; direction from residential land use planning standard for the city, and the effect of land price.
\end{abstract}

Key words: floor area ratio; spatial difference; residential quarter; Theil index; Dalian 